Section Editor

Mitchell S.V. Elkind, MD, MS

M. Dibner, MD, MPH

J. Carmody, MD

M. Strominger, MD

M. Kapadia, MD, PhD

D. Thaler, MD, PhD

Correspondence \& reprint requests to Dr. Dibner: mdibner@tuftsmedicalcenter.org

\section{Teaching NeuroImages: Bilateral subperiosteal hemorrhage of the orbit}

Figure 1 Patient's appearance 1 day after presentation, demonstrating bilateral ecchymoses and proptosis

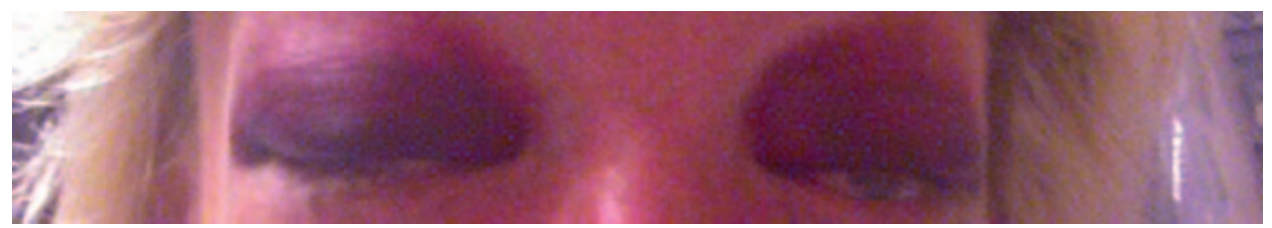

A 45-year-old woman developed swelling and ecchymoses of both upper eyelids after an episode of vomiting (figure 1). Examination demonstrated bilateral

proptosis with restriction of ocular motility. Neuroimaging showed bilateral orbital fluid collections consistent with hemorrhages (figure 2). Workup for coagulation disorders and orbital vascular anomalies was negative.

Subperiosteal orbital hemorrhages are rare and Figure 2 Coronal TI MRI

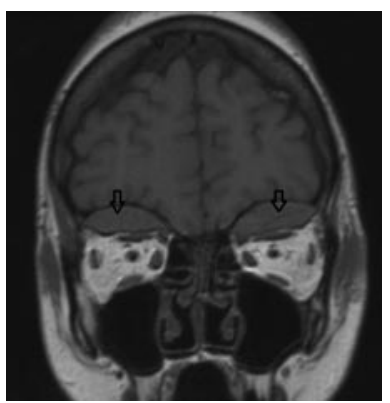

Bilateral, biconvex, superior subperiosteal masses (arrows) consistent with hemorrhage seen on coronal T1-weighted MRI image without contrast done 1 day after symptom onset. Note the mass effect on both right and left superior recti and levators palpebrae. mostly traumatic. Nontraumatic causes include increased venous pressure, coagulopathies, paranasal sinusitis, and vascular lesions. ${ }^{1}$ Patients present with retro-orbital pain, eyelid edema/ecchymosis, conjunctival chemosis, proptosis, and ophthalmoparesis. The case demonstrates that subperiosteal orbital hemorrhage can develop after vomiting in patients without risk factors and present bilaterally.

\section{AUTHOR CONTRIBUTIONS}

All authors contributed to writing and editing this case study and Dr. Kapadia provided the patient photograph.

\section{REFERENCE}

1. Atalla ML, McNab AA, Sullivan TJ, Sloan B. Nontraumatic subperiosteal orbital hemorrhage. Ophthalmology 2001;108:183-189. 


\section{Neurology}

\section{Teaching NeuroImages: Bilateral subperiosteal hemorrhage of the orbit \\ M. Dibner, J. Carmody, M. Strominger, et al. \\ Neurology 2012;78;e129 \\ DOI 10.1212/WNL.0b013e318257510d}

This information is current as of May 21, 2012

Updated Information \&

Services

References

Subspecialty Collections

Permissions \& Licensing

Reprints including high resolution figures, can be found at: http://n.neurology.org/content/78/21/e129.full

This article cites 1 articles, 0 of which you can access for free at: http://n.neurology.org/content/78/21/e129.full\#ref-list-1

This article, along with others on similar topics, appears in the following collection(s):

\section{Orbit}

http://n.neurology.org/cgi/collection/orbit

Information about reproducing this article in parts (figures,tables) or in its entirety can be found online at:

http://www.neurology.org/about/about_the_journal\#permissions

Information about ordering reprints can be found online:

http://n.neurology.org/subscribers/advertise

Neurology ${ }^{\circledR}$ is the official journal of the American Academy of Neurology. Published continuously since 1951, it is now a weekly with 48 issues per year. Copyright Copyright @ 2012 by AAN Enterprises, Inc.. All rights reserved. Print ISSN: 0028-3878. Online ISSN: 1526-632X.

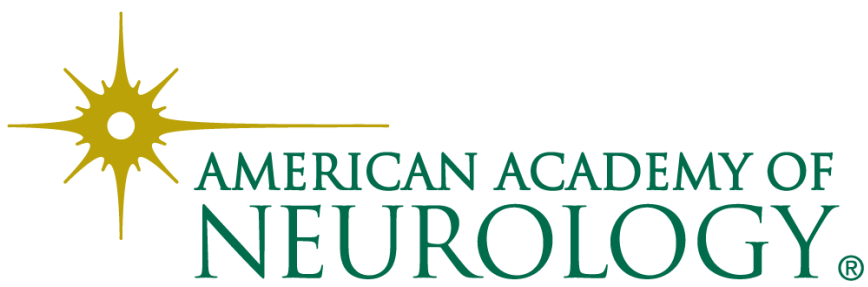

